\title{
How does Tenerife society perceive immigration?
}

Prepared by DANIEL BURASCHI and DiRK GodenAU

The social perceptions of immigration and the attitudes that Tenerife society has towards immigrants are essential aspects of the dynamics of intercultural coexistence. The Tenerife Immigration Observatory has conducted research that has shows that in general terms the society in Tenerife has a positive perception of immigration, although there is a generalized perception of comparative grievance, based on the idea that migrants are treated more favourably by public institutions.

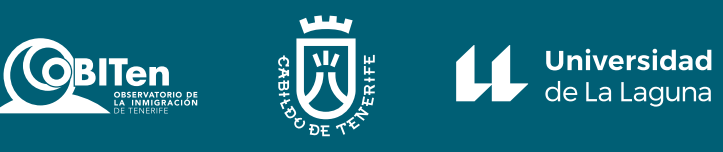


The social perceptions of immigration and the attitudes that Tenerife society has towards immigrants are essential aspects of the dynamics of intercultural coexistence. Despite their importance, there is only a small number of studies in the Canary Islands that address this issue, and none of a systematic nature containing representative samples. To date, the information available in the Canary Islands on the perception of immigration has been limited to data from the barometer of the Centre for Sociological Research; the results of the Sociobarómetro de Canarias, which included some questions in this regard spanning from 2007 to 2010; and a diagnosis based on interviews with key respondents carried out in Tenerife as part of the Anti-Rumour Strategy (De Torres \& Pinyol, 2013).

To fill this gap, the Tenerife Immigration Observatory conducted an extensive study starting in 2017, the results of which, published in Buraschi \& Godenau (2020), constitute the first systematic and representative approach to the perceptions that residents of Tenerife have of immigration. It is a broad, interdisciplinary study that triangulates the results obtained from quantitative techniques (such as a survey and analysis of press content in the Canary Islands), qualitative techniques (such as discussion groups, interviews with immigrants and key respondents), and ethnographic observation. From a methodological point of view, the study also offers a new approach by analysing the perceptions of both native islanders and non-natives (including those born on the Spanish mainland and abroad).

There is an applied utility to understanding the dynamics of coexistence, because it provides keys for designing social policies, action strategies and social initiatives to promote intercultural coexistence.

\section{What groups are associated with immigration? Which are regarded as being most similar to Canarians?}

The main groupassociated with immigration is Latin Americans (76.7\%), followed by subSaharan Africans (36.2\%) and North Africans (31.0\%). These last two groups are mentioned more frequently than their corresponding percentage in the immigrant population.

Latin Americans are clearly perceived as more similar to Canarians, both by natives $(86.9 \%)$ and non-natives (81.1\%), followed far behind by Western Europeans (11.7\%), who are perceived by non-natives $(17.4 \%)$ as being more similar to natives. By contrast, Asians (31.4\%) and North Africans (26.3\%) are most often mentioned as being the most different. Once again, the difference between natives and non-natives is wide for Western Europeans, who are perceived as more different by non-natives ( $25.7 \%$ versus $17.4 \%$ ).

This result is a reflection of the direct experience of the individuals participating in the study and of the image in the media, which overstates the population of African origin. African immigration is overestimated and people of community (EU) origin are not usually associated with immigration, but rather with a generic category of foreigners. Individuals of Latin American origin and of African origin are defined as immigrants, while people of community origin are viewed as foreigners. 


\section{How is the number of immigrants present on the island perceived?}

$51.9 \%$ of the native population regards immigration as excessive, a figure that is lower in the non-native population (36.0\%). $58.9 \%$ of non-natives view the level of immigration as adequate. This is a higher proportion compared to other studies at the local and national level (Fernández et al., 2017; Ikuspegi, 2019; OPIA VIII, 2019). This perception is not always related to the actual number of immigrants, but may depend on other factors, such as their concentration in certain areas, the homogeneity and visibility of a certain group and the speed of demographic changes, as a rapid increase in one group can result in more rejection.

It is important to note that almost half of the people of local origin overestimate the percentage of immigrants living in Tenerife. Although the exaggerated the size of minority groups could be interpreted as reflecting a greater sense of threat among the native population, this statement should be qualified, since other factors also play a role: the prominence of migrants in the media and in political discourse; the visibility of certain groups of immigrants (due to their phenotypic characteristics, their custom of frequenting public spaces, their way of dressing, etc.); the speed of demographic changes; or the personal experience of the people surveyed, who may generalise to the entire island the situation in their neighbourhood, local area or relational environment.

\section{What positive and negative effects are associated with immigration?}

$30.9 \%$ of natives do not see any positive effect from immigration, a figure that drops to $7.6 \%$ among non-natives (Table 1). In the case of negative effects, the situation is the reverse: $16.9 \%$ of the non-local population does not perceive any negative effects, in contrast to $6.9 \%$ of the native population (Table 2). In turn, the average number of mentions of the positive effects among locals (1.0) is lower than among non-locals (1.5). In the negative effects, natives elicit an average of 1.6 mentions, compared to 1.2 among non-natives.

\begin{tabular}{l|c|c|c}
\hline & $\begin{array}{c}\text { Born in the } \\
\text { Canary Islands }\end{array}$ & $\begin{array}{c}\text { Born outside the } \\
\text { Canary Islands }\end{array}$ & Total \\
\hline None & 30.9 & 7.6 & $\mathbf{2 3 . 7}$ \\
\hline Labour market & 22.8 & 27.6 & $\mathbf{2 4 . 3}$ \\
\hline Contribution to development & 36.1 & 54.4 & $\mathbf{4 1 . 7}$ \\
\hline Cultural enrichment & 45.0 & 65.9 & $\mathbf{5 1 . 4}$ \\
\hline Average number of positive & 1.0 & 1.5 & $\mathbf{1 . 2}$ \\
\hline
\end{tabular}

Table 1

Mentions of positive effects of immigration (\%)

\section{Source}

OBITen. Intergroup Perceptions Project 2017-2019.

The most cited positive effect, both in the survey and in the discussion groups, is cultural enrichment. In the discussion groups, this positive aspect is usually reduced to superficial elements such as cuisine. This result reflects the little acknowledgment that is given to the positive effects of immigration in public discourse and in the media.

With regard to the negative effects, the most frequent mentions are related to the job market, followed by safety and problems living together. The differences between natives and non-natives are particularly wide when assessing the effects of immigration on the labour market, with natives exhibiting a more pessimistic view (Table 2). 


\begin{tabular}{|c|c|c|c|c|}
\hline \multirow{3}{*}{$\begin{array}{r}\text { Table 2 } \\
\text { Mentions of } \\
\text { negative effects of } \\
\text { immigration (\%) }\end{array}$} & & $\begin{array}{l}\text { Born in the } \\
\text { Canary Islands }\end{array}$ & $\begin{array}{l}\text { Born outside the } \\
\text { Canary Islands }\end{array}$ & Total \\
\hline & None & 6.9 & 16.9 & 10.0 \\
\hline & Labour market & 52.9 & 27.3 & 45.1 \\
\hline \multirow{5}{*}{$\begin{array}{r}\text { Source } \\
\text { OBITen. Intergroup } \\
\text { Perceptions Project } \\
2017-2019 .\end{array}$} & Public services & 29.3 & 15.9 & 25.2 \\
\hline & Living together & 31.0 & 27.9 & 30.0 \\
\hline & Safety & 37.1 & 34.9 & 36.4 \\
\hline & Development & 12.7 & 9.4 & 11.7 \\
\hline & Average no. of negative effects & 1.6 & 1.2 & 1.5 \\
\hline
\end{tabular}

The results show that Canarian society perceives immigration as a multidimensional threat, which includes material elements of life (access to certain resources, safety, economic aspects) and symbolic elements such as identity and culture. Conflict, threat, and competition for certain resources do not have to be real to have an effect on perceptions (Campbell, 1965).

The negative effects are related to immigration in general, but in some cases, they are especially associated with certain groups. As evidenced by different theoretical proposals on the role of threat in social perception (Esses et al., 1998; Stephan \& Stephan, 2000), its nature depends on different factors: intergroup relations (differences in status, history of intergroup conflict, perception of group size); individual differences such as individual and group self-esteem, orientation towards domination; cultural factors; and situational factors (the characteristics of the interaction, the support, the goals, the crisis contexts or the visibility of a group of immigrants). Furthermore, to interpret these results, it is necessary to take into account not only the perceived threat, but also the relative position and social status of the natives compared to the non-natives, as this can generate what is called relative frustration. This feeling can be collective and can trigger a scapegoat mechanism through which responsibility for a social problem, such as unemployment, economic hardship or saturated public services, is transferred to immigrants (Berkowitz, 1962).

\section{What emotions arise most often when talking about immigration?}

Emotions are a central aspect of how immigration is perceived. Attitudes towards migrants can exhibit a wide emotional heterogeneity, based on the groups toward which the attitudes are directed, and some variability, depending on the context (Mackie et al., 2008; Smith, 1993). The study shows that the negative emotion that is most frequently and explicitly evoked is resentment, understood as a persistent feeling of disgust or anger towards someone who is viewed as the cause of a certain offence or damage suffered and that is manifested in hostile words or acts.

It should be noted that the basis of resentment is a perception that migrants receive more than they deserve, while the local population receives less than it deserves. Other studies on a local level have already provided evidence for this. In the Basque Country, there is a tendency to perceive migrants as the group that receives the most public aid (Ikuspegi, 2019). In Andalusia, an analysis of discussion groups reveals the perception of a comparative grievance, with people perceiving immigrants as receiving more than locals (Rinken, 2019). 
This resentment is based on the idea of a violation of the principle of equality, an idea that is socially accepted because it is framed within values that are not explicitly exclusive, but seemingly democratic. In fact, reflection in political philosophy and social sciences has highlighted the centrality of resentment as a social passion that has great political efficacy, because it is closely linked to the idea of social justice (Grandjean \& Guénard, 2012). It is a legitimation strategy that differs from prioritising citizens, that is, locals first, and that is currently enjoying a great capacity to mobilise, especially when it is exploited by populist movements (Fassin, 2017).

An analysis of the discussion groups revealed a dynamic whose understanding is critical to comprehending how social discourses can quickly transform from positive and tolerant to negative and exclusive. In almost every case, the dynamics of the discussion groups with the native population evolved along three stages: an initial phase with a clear consensus on the tolerance and openness of Canarian society; a second in which some people expressed a negative perception of the supposed privileges of migrants; and from these interventions, often expressed through personal examples, a third stage developed characterised by an unexpected change in trend, with the group reaching a consensus of rejection and intolerance towards migrants, as long as the rejection could be justified in the framework of violating the principle of equality.

This phenomenon cannot be explained solely by the fact that the participants initially feel inhibited and then become more confident, because the change occurs only when the issue of the violation of the principle of equality is raised, regardless of the time elapsed since the start of the discussion group. The discourse that can suddenly trigger a vehement rejection of immigration is characterised, as proposed in theories of democratic racism, by being morally acceptable: expressions of rejection of immigrants can be explicit, as long as they are justifiable on the basis of shared values, such as equality, justice, freedom or security.

\section{How is coexistence valued?}

Regarding the assessment of coexistence in the neighbourhood of residence, the majority consider it positive (49.8\% natives, $52.4 \%$ non-natives) or very positive (6.3\% natives, $18.6 \%$ non-natives). However, negative evaluations are more frequent among the local islanders than among non-natives.

The frequency of personal interactions with immigrants is high. $63.8 \%$ of those surveyed interact every day or almost every day with immigrants, the low frequencies being most common among natives. $7.9 \%$ of the natives stated that they never have contact with immigrants.

For the autochthonous population, these contacts involve, most of all, their work, neighbourhood or friendships, with family ties being less frequent. In the non-native population, friendship, work and family ties account for most of the interactions.

In the discussion groups, however, it was noted that many people only have superficial contact with individuals of foreign origin and that contact, by itself, does not automatically imply that the perceptions are positive. 


\section{How do attitudes vary based on the various origins?}

The levels of sympathy/antipathy clearly differ based on the origin. Starting with the negative sentiment and for the entire sample, it is the Eastern Europeans $(42.7 \%)$ and North Africans (32.6\%) who are most frequently mentioned as the groups that received little sympathy (Graph 1). In both cases, the differences between natives and non-natives are wide.

Gráph 1

Antipathy towards immigrants by origin (\%)

Fuente

OBITen. Intergroup

Perceptions Project 2017-2019.

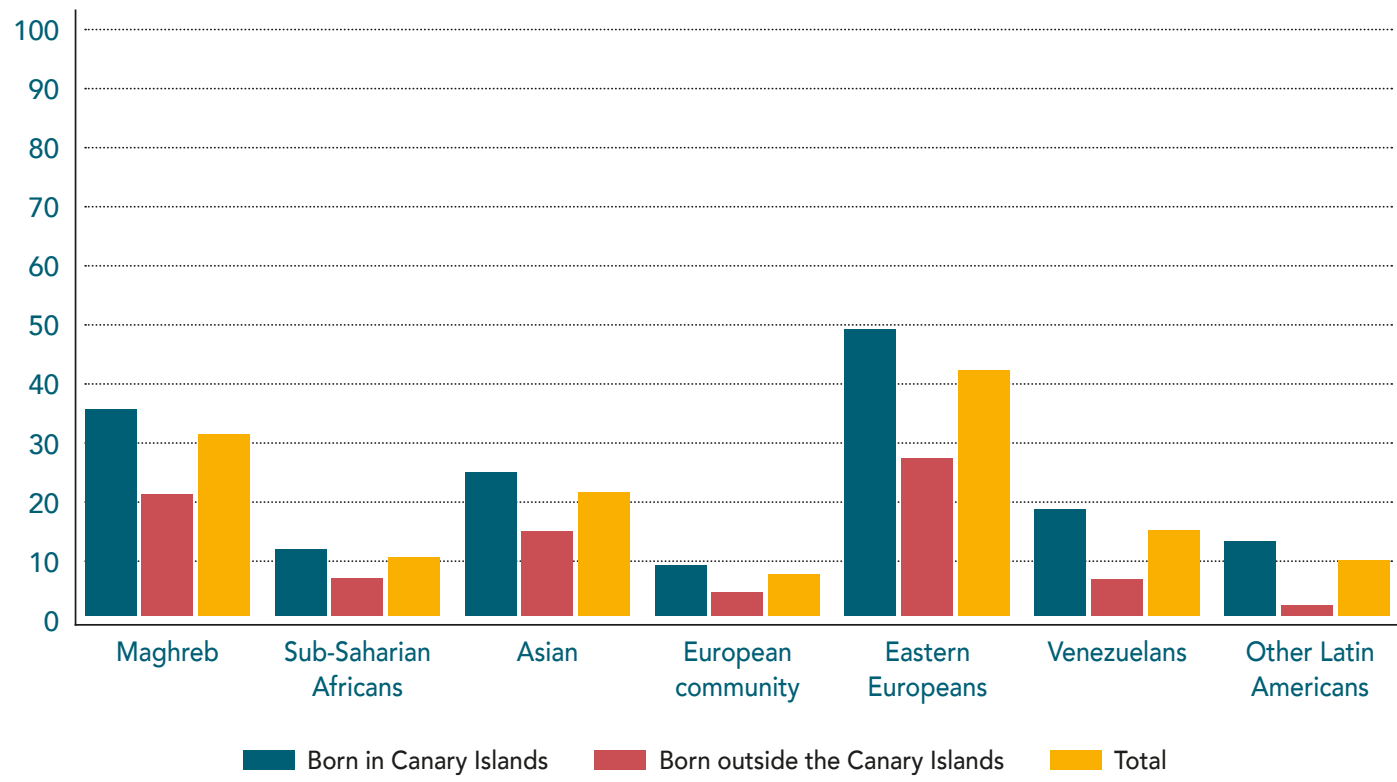

At the other extreme, the highest degree of sympathy is generated by Latin Americans (59.0\%), Western Europeans (58.4\%) and Sub-Saharan Africans (50.8\%). In this case, the differences between natives and non-natives are not wide for sub-Saharan Africans, but they are for Western Europeans and Latin Americans, groups that instil more sympathy among those born outside the Canary Islands. The specific profile of Asians is worth noting, as this group is perceived as clearly different from the Canarians, but it does not instil the same level of antipathy as Eastern Europeans and North Africans, and it has the highest levels of indifference (Graph 2).

Gráph 2

Sympathy toward immigrants by origin (\%)

Fuente

OBITen. Intergroup Perceptions Project 2017-2019.

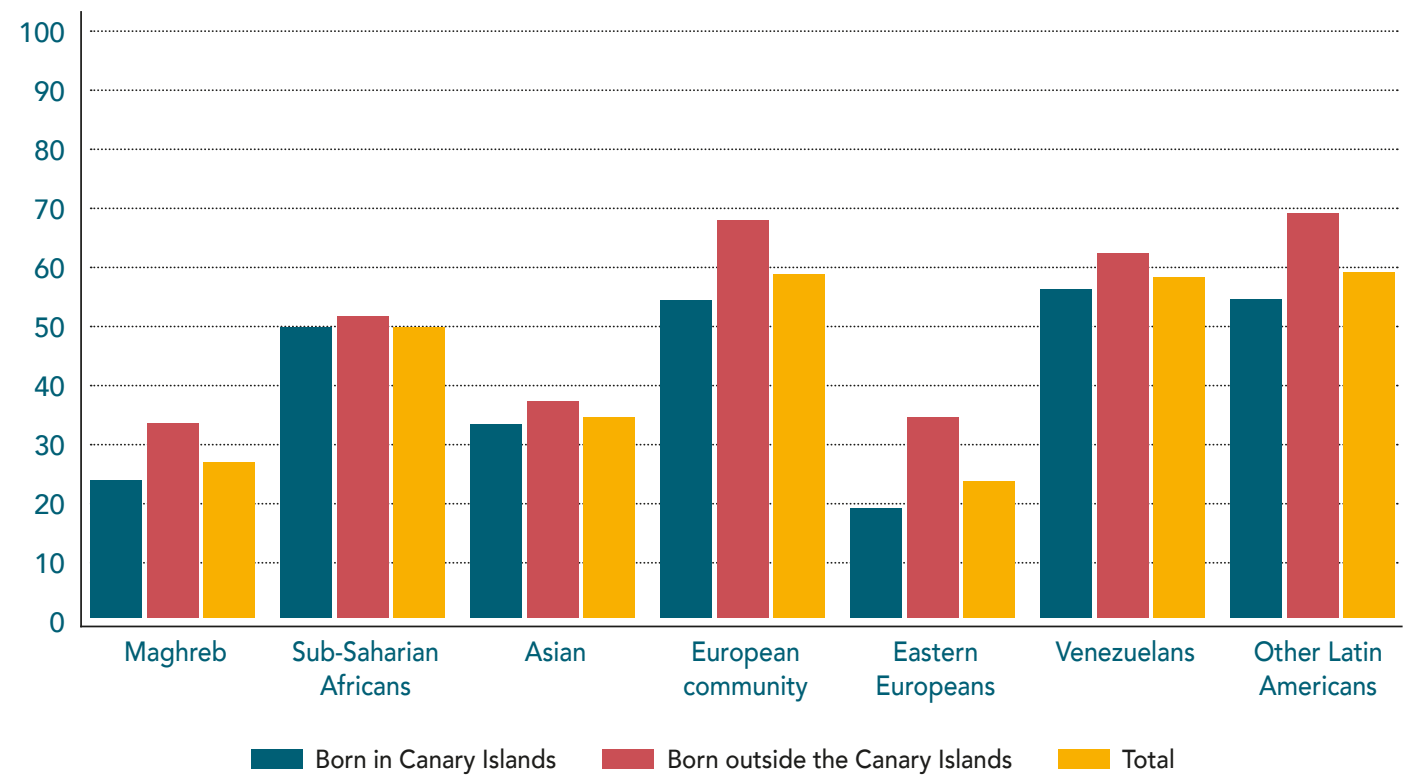




\section{How does the perception of immigration change according to sociodemographic profile?}

The results of the study confirm that the main variables that condition perception reflect a long tradition of sociological studies that show that advanced age, a right-wing political ideology and low levels of education and income lead to higher levels of antipathy toward the immigrant population (Quillian, 1995; Ceobanu \& Escandell, 2010). With regard to ideology, there is a broad consensus in social sciences linking right-wing ideology with more negative attitudes (Hainmueller \& Hiscox, 2007), although the traditional distinction between right and left has a meaning that can vary between countries and the effects of ideology may increase in contexts in which the issue of migration is politicised. Numerous studies have underscored how educational level is inversely related to negative attitudes toward immigration. This is due to different factors, including the development of more critical attitudes, greater personal and family security, as well as a greater awareness of other cultural and social realities (Chandler \& Tsai, 2001; Ceobanu \& Escandell, 2010).

For example, $51.9 \%$ of the native respondents regard immigration in Tenerife as "excessive". The range of this percentage ranges from $39.9 \%$ for people who do not self-identify as "Catholic" to $63.9 \%$ for people who describe themselves as "right-wing" (Table 3). The percentages are also higher for women, ages 45 and over, with no college education and from a low social class.

\begin{tabular}{|c|c|c|}
\hline & & Immigration is excessive \\
\hline \multirow{2}{*}{ Gender } & Male & 45,4 \\
\hline & Female & 58,0 \\
\hline \multirow{2}{*}{ Age } & $18-44$ & 42,2 \\
\hline & 45 and over & 59,7 \\
\hline \multirow{2}{*}{ Level of education } & Advanced & 41,7 \\
\hline & Other & 53,7 \\
\hline \multirow{2}{*}{ Employment situation } & Employed & 55,9 \\
\hline & Other & 48,1 \\
\hline \multirow{2}{*}{ Social class } & Low & 59,2 \\
\hline & Other & 47,4 \\
\hline \multirow{2}{*}{ Religion } & Catholic & 60,1 \\
\hline & Other & 39,9 \\
\hline \multirow{2}{*}{ Political ideology } & Right-Wing & 63,9 \\
\hline & Other & 50,0 \\
\hline \multicolumn{2}{|l|}{ Total } & 51,9 \\
\hline
\end{tabular}

Table 3

Percentage of responses in the native population by segment involving the level of immigration (\%).

\section{Sourcee}

OBITen. Proyecto OBITen. Intergroup Perceptions Project 2017-2019. 


\section{How do immigrants perceive immigration?}

Regarding how the population born outside the Canary Islands perceives immigration in Tenerife, this case also requires highlighting the internal heterogeneity of these perceptions. Although in general terms the non-native population has a more favourable perception of immigration than the native population, it is clear that the various groups that comprise immigrants in Tenerife have different perceptions of the phenomenon of immigration. As in the autochthonous population, cultural differences and economic and social stratification affect how other immigrants are perceived. Therefore, and as is widely known, immigrants do not comprise a uniform group in their perceptions. It is even possible for the gap perceived between some of these groups of non-natives to be greater than that perceived by the autochthonous population.

\section{How is Canarian society perceived?}

The results of the study show that there is a certain consensus among the indigenous population in perceiving Canarian society as open and tolerant. Two-thirds of the native population perceive Canarian society as open. This perception is shared, in part, by people of immigrant origin, although immigrants note the difficulty of gaining access to the inner circle of relationships of autochthonous people.

The broad consensus of the autochthonous population regarding the openness of Canarian society can also be explained by the existence of in-group favouritism, meaning a tendency on the part of the members of a group to favour, benefit or think better of its own members in order to maintain or achieve a positive social identity. In this case, favouritism is anchored in a collective representation in which the image of the Canarian population as open, affectionate, friendly and permeable to immigration is of great importance, by virtue of being a society of emigrants.

\section{Conclusions}

In general terms, the results of the survey and the discussion groups are in keeping with other national and local studies, and show that the perceptions of immigration are relatively positive, considering the notable problem with inequality in the Canary Islands, especially when talking about relationships, coexistence and certain groups. However, there are also some worrying signs, most notably the perception that immigration is excessive and the stigmatising attitude toward certain groups such as Eastern Europeans and North Africans, in addition to a generalised perception of comparative grievance, based on the idea that migrants are treated favourably by institutions. 


\section{For more information}

BERKOWITZ, L. (1962). Aggression: A social psychological analysis. Whitefish: Literary Licensing LLC.

BURASCHI, D. \& GODENAU, D. (coords.) (2020). La percepción de la inmigración en Tenerife. Tenerife: Cabildo de Tenerife.

CAMPBELL, D. T. (1965). "Ethnocentric and other altruistic motives". In D. Levine (coord.). Nebraska Symposium on Motivation. Lincoln: University of Nebraska Press, pp. 283311.

CEOBANU, A. M. \& ESCANDELL, X. (2010). "Comparative analyses of public attitudes toward immigrants and immigration using multinational survey data: A review of theories and research". Annual review of sociology, 36, pp. 309-328.

CHANDLER, C. R. \& TSAI, Y. M. (2001). "Social factors influencing immigration attitudes: an analysis of data from the General Social Survey". The Social Science Journal, 38(2), pp. 177-188.

DE TORRES, D. \& PINYOL, G. (2013). Identificación de estereotipos y falsos rumores. Documento de trabajo de la Red Antirrumores. Barcelona: D-Cas electronic edition.

ESSES, V. M., JACKSON, L. M. \& ARMSTRONG, T. L. (1998). "Intergroup competition and attitudes toward immigrants and immigration: An instrumental model of group conflict". Journal of social issues, 54(4), pp. 699-724.

FASSIN, É. (2017). Populisme: le grand ressentiment. Éditions Textuel.

FERNÁNDEZ, M., VALBUENA, C. \& CARO, R. (2017). Informe-Encuesta 2017. Evolución del Racismo, la Xenofobia y otras formas de Intolerancia en España. Madrid: Observatorio Español del Racismo y la Xenofobia (OBERAXE).

GRANDJEAN, A. \& GUÉNARD, F. (2012). Le ressentiment, passion sociale. Rennes: Presses universitaires de France.

HAINMUELLER, J. \& HISCOX, MJ (2007). "Educated preferences: Explaining attitudes toward immigration in Europe". International organization, 61(2), pp. 399-442.

IKUSPEGI (2019). Barómetro. Percepciones y actitudes hacia la población de origen extranjero. Bizkaia: Ikuspegi.

MACKIE, D. M., SMITH, E. R., \& RAY, D. G. (2008). "Intergroup emotions and intergroup relations". Social and Personality Psychology Compass, 2(5), pp. 1866-1880.

OBSERVATORIO PERMANENTE ANDALUZ DE LAS MIGRACIONES (2019). Opiniones y actitudes de la población andaluza ante la inmigración (OPIA VIII). Sevilla: Junta de Andalucía.

QUILLIAN, L. (1995). "Prejudice as a response to perceived group threat: Population composition and anti-immigrant and racial prejudice in Europe". American Sociological Review, 60 (4), pp. 586-611. 
RINKEN, S. (2019). "El peligro de la xenofobia. En Grupo de estudio de nivel estratégico del Comité Especializado de Inmigración". El fenómeno migratorio en España. Reflexiones desde el ámbito de la Seguridad Nacional. Madrid: Ministerio de la Presidencia, Relaciones con las Cortes e Igualdad, pp. 221-228.

SMITH, E. R. (1993). "Social identity and social emotions: Toward new conceptualizations of prejudice". In D. M. Mackie \& D. L. Hamilton (coords). Affect, cognition and stereotyping. New York: Academic Press, pp. 297-315.

STEPHAN, W. G. \& STEPHAN, C. W. (2000). "An integrated threat theory of prejudice". In S. Oskamp (Ed.). Reducing Prejudice and Discrimination. Mahwah, NJ: Lawrence Erlbaum, pp. 23-45.

How to cite this article:

BURASCHI, D. \& GODENAU, D. (2020). How does Tenerife society perceive immigration? OBITen Factsheet 6-2020. Retrieved from www.obiten.net. DOI: https://doi.org/10.25145/r.obitfact.2019.15

The Tenerife Immigration Observatory is a joint initiative of the Tenerife Council and the University of La Laguna that is intended to provide a permanent and dynamic structure to advance our scientific knowledge of migratory movements. The OBITen carries out its activity by gathering, producing and disseminating knowledge to facilitate qualified opinions and promote the making of decisions that help to better manage migratory phenomena and their implications.

http://www.obiten.net 